\title{
Stock market liquidity and firm dividend policy: Evidence from Tehran Stock Exchange
}

\author{
Hassan Ghodrati and Seyed Reza Ghazi Fini*
}

Department of Management and Accounting, Kashan Tehran Branch, Islamic Azad University, Kashan, Iran

\begin{tabular}{|c|c|}
\hline CHRON I C LE & A B S T R A C T \\
\hline $\begin{array}{l}\text { Article history: } \\
\text { Received January } 28,2014 \\
\text { Accepted 20 June } 2014 \\
\text { Available online } \\
\text { June } 262014 \\
\text { Keywords: } \\
\text { Dividend policy } \\
\text { Stock liquidity } \\
\text { Tehran Stock Exchange }\end{array}$ & $\begin{array}{l}\text { In this study, we examined the relationship between the dividend policy and shares liquidity } \\
\text { under different criteria on } 80 \text { selected firms listed on Tehran Stock Exchange over the period } \\
2007-2011 \text {. We used of Amivest, turnover, Gopalan and flow measures for shares liquidity. } \\
\text { Using some statistical tests, the study has determined that there was not any meaningful } \\
\text { relationship between Amivest liquidity with dividend policy. However, the study detected a } \\
\text { reverse relationship between turnover liquidity and with dividend policy, and direct relationship } \\
\text { between Gopalan liquidity with dividend policy and between flow liquidity with dividend } \\
\text { policy. }\end{array}$ \\
\hline
\end{tabular}

(C) 2014 Growing Science Ltd. All rights reserved.

\section{Introduction}

Dividend policy has been a question in financial management for several years and some people called it "dividend puzzle" Black (1976). Dividend decision is one of the most important concerns for any company since many private investors invest to get return. Receiving dividend is one of the ways to get return and it is a tool for making a balance between retained earnings of a company on one hand and cash payment and issuance of new shares on the other hand. It is essential for many investors to get return on investment and an added amount to the initial investment. For this reason, investors shall always decide where to invest to get more return (Khodadadi, 2009). In any financial market, depending on the extent and depth of market, there are different tools for investment and asset liquidity is one of the primary issues in investment because some investors may wish to have easy and early access to their financial investment. Fast liquidity of shares is subject to the extent that investors tend to trade shares in stock exchange. Liquidity plays an essential role in the valuation of assets because it is important for investors to determine an appropriate market to sell their assets. This is the risk of non-liquidity of assets, which prevents investors from investment in Stock Exchange. The less liquid, the less investors' interest in purchasing shares. There are evidences that liquidity 
plays essential role in decision-making. In other words, some investors may wish to have early access to their financial investment. For this reason, the power of liquidity is very importance. Liquidity is one of the positive characteristics of competitive markets. Liquidity is described as trading shares at a low cost without influencing the price within the shortest possible time. It serves as the basis for sustainability and an important factor for the study of efficiency and maturity of future markets. (Yahyazadehfar \& Larimi, 2008). In this research, the key question is that whether or not there is any relationship between dividend policies and any of shares liquidity criteria.

\section{Literature Review}

Dividend provides a reward in a sense for investors who have taken a risk by investing on shares of a certain firm. Income earned by the firm is distributed to shareholders, and frequently increases over time. Firms have several options when deciding what to do with net income. It can be distributed as dividends, but it can be kept as retained earnings or applied to repurchase firm equity shares on the secondary market. The firm's decision of which option is preferable depends on different factors, one of which is the future prospect that the firm has. If a firm has many project in mind for future growth, dividends will be held to a minimum or nothing at all. According to Modigliani and Miller (1958), investors should be indifferent as to whether or not they receive dividends now or capital appreciation in the future, an idea known as the Dividend Irrelevance Theory. In other words, an increase in current dividends must lead to a reduction in the terminal value of the existing shares since the dividend stream on the existing shares have to be diverted to absorb outside capital from which higher future dividends are paid (Griffin, 2010). Liquidity is a relatively broad concept, which in this case refers to the capability to trade large volumes quickly, at low cost, and without moving the price. Liquidity influences on the attractiveness of a stock to investors. Investors may need higher expected returns on assets whose returns are sensitive to liquidity local market. Liquidity is also an important driver of returns in emerging markets (Bekaert et al, 2007).

According to Baker and Wurgler (2004), dividend payout is determined by investor's demand, and the percentage of firms, which initiates to pay to shareholders. They examined different hypotheses based on stock price and reported that when the demand for dividend is high, no-dividend firms begin to pay dividend. Some criteria also showed that when the demand for dividend is low, dividend payer firms are willing to omit dividend. Deuskar (2006) provided a model to study liquidity behavior and share price fluctuation. In this model, investors anticipated the changes in price for the changes of a risky asset. If an asset maintains high changes, it will have high risk and reduced current yield. Under such conditions, non-risky assets have low rate of yield and market experience non-liquidity.

Ghorbani (2008) examined the relationship between stock liquidity and dividend policy based on cross sectional regression. He considered liquidity as the ratio of trading days of stock to trading days of market and trading stocks to issued stocks. Dividend policy was defined as dividend to earning per share. The research reported a positive and significant relationship between stock liquidity and dividend policy. Fakhari and Yousefali-Tabar (2010) investigated the liquidity and return of shares. In their research, liquidity measures were considered in regression equation after they were standardized. The effect of liquidity measures on the return of shares was examined using statistical procedures over the period 2000-2005. The results showed that there was a significant relationship between liquidity of each share and return of shares in the companies listed in emerging stock market. Saeidi and Behnam (2009) studied 11 factors to examine dividend policy such as firm leverage, previous year dividend, existence of investment opportunities, cash flow from firm operational activities, etc. Gill et al. (2010) analyzed the American service and manufacturing firms and found that the dividend payout ratio was a function of profit margin, sales growth, debt-to-equity ratio and tax. For the services industry, the dividend payout ratio was a function of profit margin, sales growth, and debt -to-equity ratio. For manufacturing firms, the dividend payout ratio was a function of profit margin, tax and market-to-book ratio. Yahyazadehfar and Khorramdin (2011) studied the relationship 
between risk and efficiency, the effect of non-liquidity risk and liquidity factors such as market return excess, size of company and ratio of book value to market value. In their study, they used time series model over the period 1999-2005. They reported that non-liquidity and size of company had negative effect on shares return excess; however, the effects of market return excess and ratio of book value to market value on shares return excess were positive. Sirani et al. (2011) performed an investigation on the relationship between the disclosure quality of financial information and securities liquidity in the companies listed in stock markets. They focused on transparent financial statements and disclosure quality of information provided via information systems as a viable approach, which could reduce information asymmetry. Both theoretical analysis and empirical evidence indicated that increased information asymmetry between company managers and shareholders was associated with decreased number of investments, decreased securities liquidity lower volume of trading and decreased social benefits derived from trading.

\section{Research Hypotheses}

Main hypothesis: There is a relationship between dividend policy and measures of liquidity.

\section{Sub-Hypotheses:}

1. There is a relationship between dividend policy and Amivest liquidity (Goyenko et al., 2009).

2. There is a relationship between dividend policy and turnover liquidity.

3. There is a relationship between dividend policy and Gopalan liquidity (Gopalan et al., 2012).

4. There is a relationship between dividend policy and cash flow liquidity.

\section{Research methodology}

In terms of objective, this research is of applied type. In terms of the type of research design relying on historical data, this research is of casual type. The inductive reasoning is of correlation type.

\subsection{Statistical population and sampling}

The population of this survey includes the companies listed on Tehran Stock Exchange, which are not of investment or financial intermediary entity and disclose their information. There were 80 companies selected using Morgan table and stratified random sampling method. The performance of these companies has been subject of study on the basis of performance data over the period 20072011 .

\subsection{Data analysis method}

In this research, descriptive statistical methods such as calculation of mean, variance, standard deviation and classified and simplified table and graphic charts (Bar chart, linear chart, histogram and other charts) have been used. Kolmogorov-Smirnov (KS) test has been used for the evaluation of

normal distribution of variables. Combined linear regression has been used for the analysis of the relationship between variables and t-test and f-test have been used for the generalization of parameters and estimated relations.

\subsection{Research model}

The relationship between variables are defined in the general form of $Y=F\left(X_{1}, X_{2}, X_{3}, X_{4}\right)$ in which the dependent variable is dividend policy and independent variables are Amivest liquidity, turnover liquidity, Gopalan liquidity and liquidity flow.

Dividend policy: Ratio of divided profit to net profit 
Amivest liquidity: The ratio of transaction value per share to transaction value of the shares of company.

Turnover liquidity: The ratio of traded shares value to company shares volume.

Gopalan liquidity: The ratio of total cash to the book value of company assets.

Flow liquidity: The ratio of transactions value to wait time.

Wait time is an interval between two consecutive trades of a share.

The average wait time is usually calculated for a specified period.

Wait time of trade has been calculated on the basis of days, which shows the number of days (wait time) it takes for trading a share in average. Since, this calculation is done in annual basis, the number of 240 is the numerator of fraction as the number of the days of trade per year.

The relationship between variables is calculated on the basis of combined linear regression in parametric form as follows:

$Y\left(D I V_{i t}\right)=\alpha+\beta_{1} A M I_{i t}+\beta_{2} N G_{i t}+\beta_{3} J O P_{i t}+\beta_{4} J A_{i t}$

\section{Findings}

In this research, 80 companies have been selected in random stratified sampling method. The performance of the companies has been studied for the period of 2007-2011.

First, the observations are described. Then, the assumptions of using combined linear regression method are analyzed. Finally, the relationship between variables is studied.

\subsection{Description of findings}

A summary of the findings for describing the variables is shown in Table 1. In this table, variables have been coded for the calculation of statistical indicators.

\section{Table 1}

Description statistical indicators

\begin{tabular}{ccccc}
\hline Variable & Mean & Standard deviation & Coefficient of skewedness & Coefficient of elongation \\
\hline DIV & 0.498 & 0.933 & 2.744 & 9.212 \\
AMI & 66542 & 278760.82 & 7.540 & 61.673 \\
NG & 0.769 & 0.19017 & 10.965 & 161.323 \\
GOP & 0.452 & 0.5892 & 4.873 & 47.260 \\
JA & 347265 & 4287321 & 19.492 & 385.769 \\
\hline
\end{tabular}

\subsection{Analysis of assumptions}

In order to use combined linear regression, an analysis has been made of the relevant assumptions including normality of variables distribution, stability of variances and linear independence of independent variables. In order to study the normality of variables, Kolmogorov test has been used. A summary of the results is presented in Table 2.

\section{Table 2}

A summary of the results of normal distribution of variables

\begin{tabular}{lccc}
\hline Variable & K-S statistic & Degrees of freedom & Significant level \\
\hline DIV & 0.227 & 400 & 0.00 \\
AMI & 0.406 & 400 & 0.00 \\
NG & 0.343 & 400 & 0.00 \\
GOP & 0.223 & 400 & 0.00 \\
JA & 0.468 & 400 & 0.00 \\
\hline
\end{tabular}

As significance level in the last column shows that all values are close to zero $(<50 \%)$. For this reason, normal distribution of variables is refused in $95 \%$ level of significance. To solve this problem, logarithm transform has been used and normality of variables test has been conducted. Normal distribution of variables has finally been established at the level of 95\%. Homoscedasticity (another 
assumption of combined linear regression) has been tested using White test. The results of this test have been showed for each five estimated regression relationships (see Table 3).

Table 3

The results of White homoscedasticity test

\begin{tabular}{cccc}
\hline Model & Description & Statistical value & Probability \\
\hline Model \# 1 & F-statistic & 1.6625 & 0.0960 \\
& Obs*R-squared & 3.3357 & 0.0854 \\
\hline Model \# & F-statistic & 1.3685 & 0.0980 \\
& Obs*R-squared & 3.1028 & 0.0743 \\
\hline Model \# 3 & F-statistic & 1.9512 & 0.0982 \\
& Obs*R-squared & 3.3658 & 0.0745 \\
\hline Model \# 4 & F-statistic & 1.3685 & 0.0884 \\
& Obs*R-squared & 3.3147 & 0.0965 \\
\hline Model \# 5 & F-statistic & 1.5620 & 0.0906 \\
& Obs*R-squared & 3.4510 & 0.0883 \\
\hline
\end{tabular}

On the basis of the level of significance in the test column, homoscedasticity is accepted in the level of $95 \%$ because all values are above $5 \%$. In order to study the independent variables, Pearson product moment correlation coefficient has been used. The approximation of this coefficient to zero shows that the dependence of the variables can be ignored. A summary of the results is showed in Table 4 .

Table 4

Correlation coefficient of independent variables

\begin{tabular}{|c|c|c|c|c|c|}
\hline Variable & DIV & DIV & DIV & DIV & DIV \\
\hline DIV & 1 & & & & \\
\hline AMI & -0.044 & 1 & & & \\
\hline NG & -0.004 & -0.022 & 1 & & \\
\hline GOP & 0.003 & 0.036 & -.002 & 1 & \\
\hline JA & 0.002 & 0.015 & 0.042 & 0.37 & 1 \\
\hline
\end{tabular}

In order to choose between panel data and integrated data, F-Lamer test, in which the hypothesis of equal intercept is examined, has been used. A summary of the results is shown in Table 5. Significance is below 5\% in all cases. Therefore, the hypothesis of equal intercept is accepted for each five estimated regression relationships and a panel method can be used.

Table 5

The results of F-Lamer test for intercept equality

\begin{tabular}{lcccc}
\hline Research models & F-statistic & Degree of freedom & p-value & Test result \\
\hline Model (1) & 1.356247 & $(79,318)$ & 0.0360 & $\mathrm{H}_{\mathrm{o}}$ is accepted \\
Model (2) & 2.323087 & $(79,318)$ & 0.0265 & $\mathrm{H}_{\mathrm{o}}$ is refused \\
Model (3) & 0.0265 & $(79,318)$ & 0.0280 & $\mathrm{H}_{\mathrm{o}}$ is refused \\
Model (4) & 1.854240 & $(79,318)$ & 0.0090 & $\mathrm{H}_{\mathrm{o}}$ is refused \\
Model (5) & 1.985447 & $(79,318)$ & 0.0040 & $\mathrm{H}_{\mathrm{o}}$ is refused \\
\hline
\end{tabular}

The effect of explanatory variable on dependent variable (dividend) has been studied using the data of financial statements of 80 sample companies. The results of Pearson product moment correlation coefficient are showed in Table 6. Given the level of coefficient correlation and the level of significance between two variables of dividend policy and Amivest liquidity, it is concluded that there was no correlation between the above-mentioned variables and that there was no significant level of significance. Therefore, there is no significance correlation between these two variables. Given the level of correlation coefficient and the level of significance between the variables of dividend policy and turnover liquidity, Gopalan liquidity and cash flow liquidity, it is concluded that there was a correlation between these variables and a significant level of significance. Therefore, there is significant correlation between these variables. Afterwards, the relationship between dividend 
policy, Amivest liquidity, turnover liquidity, Gopalan liquidity and cash flow liquidity have been studied in two levels of small-sized and large-sized companies, companies with high ratio of book value to market value and those with low ratio of book value to market value.

\section{Table 6}

The Results of correlation Analysis for Research Variables

\begin{tabular}{|c|c|c|}
\hline Variables & & $\begin{array}{l}\text { Pearson product moment } \\
\text { correlation coefficient }\end{array}$ \\
\hline \multirow{3}{*}{ Dividend policy \& Amivest liquidity } & PPMCC & 0.059 \\
\hline & Level of significance & 0.236 \\
\hline & Numbers & 400 \\
\hline \multirow{3}{*}{ Dividend policy \& turnover liquidity } & PPMCC & -0.548 \\
\hline & Level of significance & 0.044 \\
\hline & Numbers & 400 \\
\hline \multirow{3}{*}{ Dividend policy \& Gopalan liquidity } & PPMCC & 0.721 \\
\hline & Level of significance & 0.005 \\
\hline & Numbers & 400 \\
\hline \multirow{3}{*}{ Dividend policy \& flow liquidity } & PPMCC & 0.638 \\
\hline & Level of significance & 0.014 \\
\hline & Numbers & 400 \\
\hline
\end{tabular}

For this purpose, the companies have been classified into two categories of small-sized and largesized companies and the companies with high ratio of book value to market value and the companies with low ratio of book value to market value. Then, correlation has been studied separately for each level. The results indicated that:

1. There is no significant correlation between two variables of dividend policy and Amivest liquidity ratio in two levels of small-sized and large-sized companies and the companies with high ratio of book value to market value and low ratio of book value to market value.

2. There is a significant correlation between two variables of dividend policy and turnover liquidity ratio in two levels of small-sized and large-sized companies and the companies with high ratio of book value to market value and low ratio of book value to market value. This correlation is more in large- sized companies and the companies with low ratio of book value to market value.

3. There is a significant correlation between two variables of dividend policy and Gopalan liquidity ratio in two levels of small-sized and large-sized companies and the companies with high ratio of book value to market value and low ratio of book value to market value. This correlation is more in large- sized companies and the companies with low ratio of book value to market value.

4. There is a significant correlation between two variables of dividend policy and cash flow liquidity ratio in two levels of small-sized and large-sized companies and the companies with high ratio of book value to market value and low ratio of book value to market value. This correlation is more in large- sized companies and the companies with low ratio of book value to market value.

In view that all assumptions for using linear regression have been tested and the results showed that linear regression method can be used, models 2, 3 and 4 are estimated in regression using panel data model and Eviews software because a significant correlation has been found between the variables of hypotheses 2 and 4 (model 2-4).

Based on similar research methodology and econometric preliminaries, in this section it was utilized the multi-variables linear-regression for variable relation analysis:

1) The relationship between dividend policy and turnover liquidity: The multi-variables Linearregression was used for this reason. The summary of parameters estimation is showed on Table 7: 
Table 7

Regression estimation for the relationship between dividend policy and turnover liquidity

\begin{tabular}{ccccc}
\hline Variables & Acronym & Coefficient & T-statistic & p-value \\
\hline Constant coefficient & $\beta_{0}$ & -3.318522 & -16.750 & 0.00 \\
Turnover liquidity & LNNG & -0.067657 & -1.223145 & 0.0440 \\
\hline
\end{tabular}

Adjusted $\mathrm{R}^{2}=0.301242, \mathrm{~F}$-value $=3.49$ sig. value $=0.044099$ Durbin-Watson $=1.8180$

After substituting parameters on regression equation, the relation of variables is explained as follows:

$L N D I V_{i t}=-3.31-0.067 L N N G_{i t}$

As shown in the above-mentioned regression model, there is a negative significant correlation between dividend policy and turnover liquidity. The study of adjusted $\mathrm{R}^{2}(0.301)$ showed the high explanatory power of this model in describing dependent variable. Therefore, there is a significant and reverse linear relationship between dividend policy and turnover liquidity.

\section{2) The relationship between dividend policy and Gopalan liquidity}

The multi-variables Linear-regression was used for this reason. The summary of parameters estimation is showed on Table 8

Table 8

Regression estimation for the relationship between dividend policy and Gopalan liquidity

\begin{tabular}{lcccccccc}
\hline Variables & Acronym & Coefficient & T-statistic & p-value & $\begin{array}{c}\text { Adjusted } \\
\mathrm{R}^{2}\end{array}$ & $\begin{array}{c}\text { F-statistic } \\
\text { Sig. level }\end{array}$ & $\begin{array}{c}\text { Durbin- } \\
\text { Watson }\end{array}$ & $\begin{array}{c}\text { Number of } \\
\text { observation }\end{array}$ \\
\hline $\begin{array}{l}\text { Constant } \\
\text { coefficient }\end{array}$ & $\beta_{0}$ & -2.457128 & -10.30366 & 0.00 & 0.516573 & 7.707401 & 1.811485 & 400 \\
$\begin{array}{l}\text { Gopalan } \\
\text { liquidity }\end{array}$ & LNGOP & 0.175592 & 2.776221 & 0.0058 & & 0.005760 & \\
\hline
\end{tabular}

After substituting parameters on regression equation, the relation of variables is explained as follows:

$\mathrm{LNDIV}_{\text {it }}=-2.45+0.0175$ LNGOP $_{\text {it }}$

As shown in the above-mentioned regression model, there is a positive significant correlation between dividend policy and Gopalan liquidity. The study of adjusted $R^{2}(0.516)$ showed the high explanatory power of this model in describing dependant variable. Therefore, there is a significant and positive linear relationship between dividend policy and Gopalan liquidity.

\section{3) The relationship between dividend policy and flow liquidity:}

The multi-variables Linear-regression was used for this reason. The summary of parameters estimation is showed on Table 9 as follows,

Table 9

Regression estimation for the relationship between dividend policy and flow liquidity

\begin{tabular}{lcccccccc}
\hline Variables & Acronym & Coefficient & T-statistic & p-value & $\begin{array}{c}\text { Adjusted } \\
\mathrm{R}^{2}\end{array}$ & $\begin{array}{c}\text { F-statistic } \\
\text { Sig. level }\end{array}$ & $\begin{array}{c}\text { Durbin- } \\
\text { Watson }\end{array}$ & $\begin{array}{c}\text { Number of } \\
\text { observation }\end{array}$ \\
\hline $\begin{array}{l}\text { Constant } \\
\text { coefficient }\end{array}$ & $\beta_{0}$ & -3.8788 & -11.8686 & 0.00 & 0.412334 & 5.986632 & 1.819 & 400 \\
$\begin{array}{l}\text { flow } \\
\text { liquidity }\end{array}$ & LNJA & 0.0798 & 2.446760 & 0.0148 & & 0.014866 & \\
\hline
\end{tabular}


After substituting parameters on regression equation, the relation of variables is explained as follows:

$\mathrm{NDIV}_{\text {it }}=-3.87+0.079$ LNJA $_{\text {it }}$

As shown in the above-mentioned regression model, there is a positive significant correlation between dividend policy and flow liquidity. The study of adjusted $\mathrm{R}^{2}(0.412)$ showed the high explanatory power of this model in describing dependent variable. Therefore, there is a significant and positive linear relationship between dividend policy and flow liquidity.

\section{3) The relationship between dividend policy and liquidity Criteria:}

The multi-variables Linear-regression was used for this reason. The summary of parameters estimation is showed on Table 10:

Table 10

Regression estimation for the relationship between dividend policy and liquidity criteria

\begin{tabular}{lccc}
\hline Variables & Acronym & Coefficient & T-statistic \\
\hline Constant coefficient & $\beta_{0}$ & -3.314098 & -7.713744 \\
Amivest liquidity & LNAMI & 0.016748 & 0.403183 \\
Turnover liquidity & LNNG & -0.00149 & -2.0048 \\
Gopalan liquidity & LNGOP & 0.176794 & 0.00 \\
Flow liquidity & LNJA & 0.071590 & 0.0492 \\
\hline
\end{tabular}

Adjusted $\mathrm{R}^{2}=0.6248, \mathrm{~F}$-value sig. value $=0.007492$ Durbin-Watson $=1.8674$

The quantity of regression F-statistic shows the high explanatory power of this model because the calculated quantities of $\mathrm{F}$ are significant in the error level of 0.05 . The quantities of Durbin-Watson also show that there is an autocorrelation between disruption components of the model because the quantities are in the interval of 1.5-2.5. According to the calculated t-statistics (shown in Table 6) and the associate probability, the estimated coefficients of linear model for the variables of turnover liquidity, Gopalan liquidity and flow liquidity are significant in the error level of 5\%. It is necessary to use these estimated coefficients in this model. Therefore, there is a significant linear relationship between dividend policy and the measures of turnover liquidity, Gopalan liquidity and flow liquidity in the companies listed in Tehran Stock Exchange. After substituting parameters on regression equation, the relation of variables is explained as follows,

$L N D I V_{i t}=-3.31-0.001 L N N G_{i t}+0.176 L_{N G O P}{ }_{i t}+0.0741 J_{i t}$

As shown in this model, there is a negative relationship between dividend policy and turnover liquidity, a positive relationship between dividend policy and Gopalan liquidity and a significant and positive relationship between dividend policy and flow liquidity. In this model, the adjusted $\mathrm{R}^{2}$ quantity (0.624) showed the high explanatory power of linear model to describe dependent variable.

4) The Summary of Variables Relation Analysis: Based on the previous variables relation, the summary of these results showed on Table 11.

\section{Conclusion}

The present research aims to study the relationship between measures of the Amivest liquidity, turnover liquidity, Gopalan liquidity and flow liquidity to dividend policy in 80 companies listed in Tehran Stock Exchange over the period 2008-2012. After the research hypotheses and subhypotheses were put forward and tested, the following results were achieved.

1. There is no significant correlation between dividend policy and Amivest liquidity.

2. There is a significant and negative relationship between dividend policy and turnover liquidity.

3. There is a significant and direct relationship between dividend policy and Gopalan liquidity.

4. There is a significant and director relationship between dividend policy and flow liquidity. 
Table 11

A summary of the finding of the study of the relationship between the variables of the research

\begin{tabular}{lcccccc}
\hline \multicolumn{1}{c}{ Variables } & Adj. $^{2}$ & D. Watson & F-statistic & t-statistic & Sig. level & result \\
\hline Amivest liquidity with dividend policy & 0.0034 & 1.83 & 0000 & 0000 & 0.05 & Rejected \\
Turnover liquidity with dividend policy & 0.301 & 1.81 & 3.49 & -1.22 & 0.05 & Accepted \\
Gopalan liquidity with dividend policy & 0.516 & 1.82 & 7.70 & 2.77 & 0.05 & Accepted \\
Flow liquidity with dividend policy & 0.412 & 1.81 & 5.98 & 2.44 & 0.05 & Accepted \\
& & & & 0.403 & & \\
Amivest, turnover, Gopalan \& cash & 0.624 & \multirow{2}{*}{1.86} & 10.53 & -2.004 & 0.05 & Accepted \\
flow liquidity with dividend policy & & & & 2.79 & & \\
& & & & 2.085 & & \\
\hline
\end{tabular}

\section{Acknowledgement}

The authors would like to thank the anonymous referees for constrictive comments on earlier version of this paper

\section{References}

Appannan, S., \& Sim, L. W. (2011). A Study on Leading Determinants of Dividend Policy in Malaysia Listed Companies for Food Industry Under Consumer Product Sector. In $2^{\text {nd }}$ International Conference on Business and Economic Research (Vol. 2).

Bekaert, G., Harvey, C. R., \& Lundblad, C. (2007). Liquidity and expected returns: Lessons from emerging markets. Review of Financial Studies, 20(6), 1783-1831.

Baker, M., \& Wurgler, J. (2004). A catering theory of dividends. The Journal of Finance, 59(3), $1125-1165$

Banerjee, S., Gatchev, V. A., \& Spindt, P. A. (2007). Stock market liquidity and firm dividend policy. Journal of Financial and Quantitative Analysis, 42(02), 369-397.

Black, F. (1976). The dividend puzzle. The Journal of Portfolio Management,2(2), 5-8.

Deuskar, P. (2006, March). Extrapolative expectations: Implications for volatility and liquidity. In AFA 2007 Chicago Meetings Paper.

Fakhari, H., \& Yousefali-Tabar, N. (2010). A study of the relationship between dividend policies and corporate governance in the companies listed in Tehran Stock Exchange. Accounting and Auditing Studies, 62, 69-84.

Ghorbani, A. (2008). A study of the relationship between stock liquidity and dividend policy. Faculty of Management and Accounting of Shahid-Beheshti University, Master's Thesis.

Gopalan, R., Kadan, O., \& Pevzner, M. (2012). Asset liquidity and stock liquidity. Journal of Financial and Quantitative Analysis, 47(02), 333-364.

Goyenko, R. Y., Holden, C. W., \& Trzcinka, C. A. (2009). Do liquidity measures measure liquidity?. Journal of Financial Economics, 92(2), 153-181.

Griffin, C. H. (2010). Liquidity and dividend policy: international evidence. International Business Research, 3(3), 3.

Gill, A., Biger, N., \& Tibrewala, R. (2010). Determinants of dividend payout ratios: evidence from United States. The Open Business Journal, 3(1), 8-14.

Khodadadi, V. (2009). Evaluation of relationship between institutional ownership structure and dividend policies in Iran. Financial Accounting Periodical, 1(2), 106-126.

Modigliani, F., \& Miller, M. H. (1958). The cost of capital, corporation finance and the theory of investment. The American economic review, 48(3), 261-297.

Saeidi, A., \& Behnam, K. (2009). A study of the effective factors in dividend policy of the companies listed on Tehran Stock Exchange. Pajouheshgar Periodical, 18, 61-71. 
Sirani, M., Hejazi, R., \& Keshavarz, M. (2011). Investigating the effect of the risk of liquidity and other factors affecting intermittent returns in the companies listed in Tehran Stock Exchange. Journal of Financial Accounting Research, 3(1), 113-124.

Yahyazadehfar, M., Shams, SH., \& Larimi, S.J. (2008). A study of relationship between liquidity and return of shares listed in Tehran Stock Exchange. Financial Researches, 12(29), 111-138.

Yahyazadehfar, M., \& Khorramdin, J. (2010). A study of relationship between liquidity and return of shares listed on Tehran Stock Exchange. Accounting and Auditing Studies, 15(53), 101-118. 